\title{
Characterization of physical and chemical properties of fuel containing animal waste
}

\author{
M. Wzorek \\ Opole University of Technology, Poland
}

\begin{abstract}
This paper includes the results of research devoted to the application of meat and bone meal as a component of granulated alternative fuel for use in the cement industry. This paper presents the composition of the fuel along with the method of its production. The paper later undertakes an analysis of chemical and physical characteristics of the resulting fuel with particular emphasis on the combustion properties, content of noxious substances and strength prosperities.

Keywords: animal by-products, meat and bone meal, alternative fuels, cement industry.
\end{abstract}

\section{Introduction}

Animal by-products generated by the food industry require the application of special treatment techniques due to the hazard they pose to the environment. Because of bacteriological hazard, the intensive, foul smell and difficulties in storing, it is necessary to ensure its fast utilization.

In the utlization plants, the animal by-products undergo the processes of grinding, drying, sterilization and degreasing, which result in the formation of animal meal and fats. In Poland, a total mass of 685,000 tons of animal waste undergoes utilization; however, forecasts say that the volume may reach 770,000 tons within the next 5 to 7 years [1]. The volume of the generated animal by-products in the selected European states is presented in fig. 1.

Depending on the type of the utilized waste, the latter originates from a variety of animal meals: bone meal, meat meal, meat and bone meal, poultry meal and fish meal. The data collected indicate that the output of utilization plants in Poland amounts to around $250 \mathrm{~kg}$ of meal and $100 \mathrm{~kg}$ of fat out of each ton of animal waste [1]. 


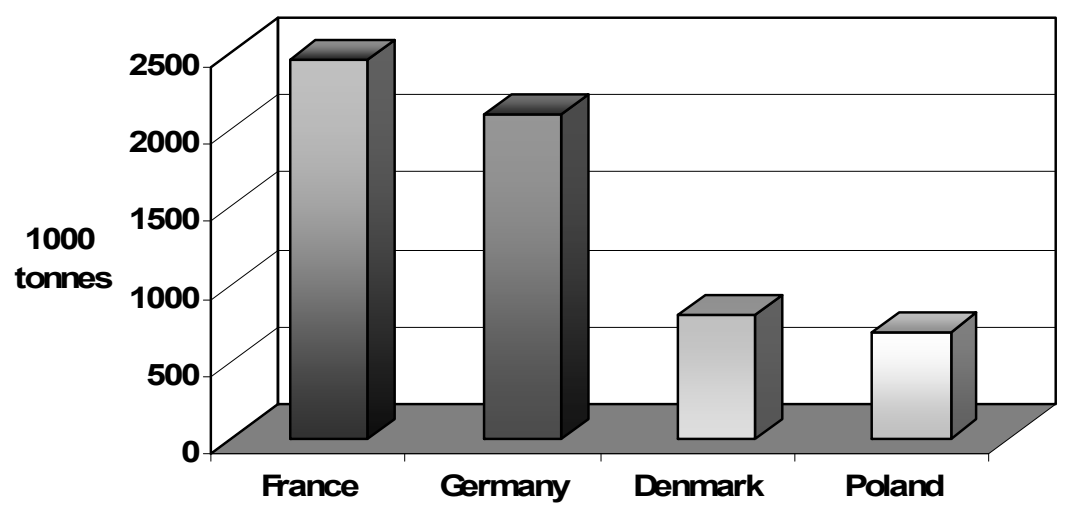

Figure 1: Production of animal by-products in selected European countries [1].

Until now the meat and bone meal (MBM) was mainly applied as a component of feed for farm animals. However, in connection with the threat resulting from the spread of BSE disease and the probability of its effect on humans, the application of meals in feeding farm animals was subjected to strict formal control [2].

Nowadays one disposal option is combustion or the co-combustion of MBM with coal, which ensures that any living organism is totally destroyed and at the same time valorizing its energetic potential [3-6]. The properties which promote the combustion of MBM in industrial processes include the low moisture content, the high calorific value, which is similar to the calorific value of low quality hard coal, and sulfur content lower than that for the case of a majority of brown coal sorts. Properties of animal meal are presented in table 1.

Table 1: Energy parameters of animal waste [7].

\begin{tabular}{|c|c|c|c|c|}
\hline Parameter & Unit & Bone meal & Meat meal & Blood meal \\
\hline LHV & $\mathrm{MJ} / \mathrm{kg}$ & $13.8-14.1$ & $17.3-25.0$ & $21.9-23.4$ \\
\hline Moisture & $\%$ & $3.3-4.9$ & $0.5-7.0$ & $3.9-4.0$ \\
\hline Ash & $\%$ d.m. & $34.5-41.4$ & $10.9-20.5$ & $1.4-1.6$ \\
\hline \multicolumn{5}{|c|}{ Elementary analysis } \\
\hline $\begin{array}{l}\text { Carbon C } \\
\text { Nitrogen N } \\
\text { Hydrogen H } \\
\text { Sulphur S } \\
\text { Oxygen O } \\
\end{array}$ & $\begin{array}{c}\% \\
\text { d.m. }\end{array}$ & $\begin{array}{c}30.5-33.3 \\
3.5-51.8 \\
7.3-7.9 \\
4.4-4.7 \\
0.10-0.25 \\
\end{array}$ & $\begin{array}{c}40.5-43.8 \\
7.7-10.4 \\
4.1-5.3 \\
0.3-0.5 \\
13.9-20.0\end{array}$ & $\begin{array}{c}51.8-52.0 \\
15.6 \\
6.5 \\
0.64 \\
-\end{array}$ \\
\hline
\end{tabular}

d.m. - in dry mass 
However, such factors as the MBM tendency towards displaying powdery characteristics, biological activity and considerable grease content account for the limitations in the application of the meal in the existing installations. Technical problems are associated with the tendency of MBM to form powder and the grease contained in the meal, which results in clogging of the transportation pipes. Biological activity, which is revealed in the conditions of high moisture content, is demonstrated in the processes of decay and hence is associated with health threat to the personnel involved. The variable moisture and fat content in meals and changeable chemical composition result in the necessity to apply specific solutions with regard to combustion conditions and transportation.

This paper includes a presentation of a technique of MBM application to form granulated fuel, which may secure an alternative of an installation in which the input of meal in its powder form may be inadvisable.

\section{Materials and methods}

As a result of the huge demand for supplementary sources of energy in the form of supplementary fuels, a new fuel designated for application in the process of cement clinker burning resulted from this research.

This fuel applies MBM along with sewage sludge from a municipal waste treatment plant. The application of the other component of the fuel results from the physical properties of the sludge. Since the sewage sludge has a high moisture content, its combination with MBM results in a mixture with moisture content in the range of 40 per cent, which enables its formation into granulate. The properties of the components of the fuel are summarized in table 2 .

Table 2: Characteristics of components.

\begin{tabular}{|c|c|c|c|}
\hline Parameter & Unit & MBM & Sewage sludge \\
\hline Physical form & - & Grounding $\geq 4 \mathrm{~mm}$ & Pasty consistence \\
\hline LHV & $\mathrm{MJ} / \mathrm{kg}$ & 17.45 & $10.73^{*}$ \\
\hline HHV & $\mathrm{MJ} / \mathrm{kg}$ & 19.18 & 11.62 \\
\hline Moisture & $\%$ & 5.31 & 71.20 \\
\hline Volatile matter & $\%$ & 65.21 & $49.33^{*}$ \\
\hline Ash & $\%$ & 20.46 & $35.61^{*}$ \\
\hline
\end{tabular}

* - in dry mass

The fuel formation was possible in a specially designed drum granulator designed for formation of fuel from waste. The drum is equipped with a special batching system which results in obtaining a granulate diameter in the range from 15 to $35 \mathrm{~mm}$ [8]. The method of fuel production consists of the initial mixing of the components at fixed ratios and the subsequent granulation and drying in the drum dryer. The fuel based on bone and meat meal and sewage sludge was named PBM fuel.

The PBM fuel was subsequently subjected to testing aimed at the determination of the combustion and physical properties, including: 
a. heating value using Oxygen Bomb Calorimeter KL-Mn,

b. elementary analysis with Elementar Analyzer Vario Macro EL,

c. heavy metal content with ICP MS Perkin Elmer Elan 6100 Mass Spectrometer,

d. chemical composition of ash with Atomic Absorption Spectrometry ASA method,

e. polychlorinated biphenyles (PCBs) with Agilent $6890 \mathrm{~N}$ gas chromatograph with ECD detector,

f. thermal and thermogravimetric analysis was performed using NETZSCH STA 4009EP differential thermal analyzer within temperature range of $0 \div 1400^{\circ} \mathrm{C}$ in oxygen atmosphere,

g. strength drop in accordance with PN-G-04651: 997 standard,

h. bulk density in accordance with PN-ISO 567:1999 standard.

\section{Results and discussion}

The application of alternative fuel in the processes of cement linker burning is subjected to numerous technical and technology related restrictions. This is because the fuel supplement with waste must not have a negative effect on the process of cement production in the kiln and, consequently, on the quality of the resulting clinker and the emission levels. In connection with the above, the fuel used in clinker production is required to conform to the required physical and chemical properties.

The properties of the fuel derived from meat and bone meal and sewage sludge was compared with the requirements specified by the cement industry concerning alternative fuels. The most comprehensible effect on the applicability of the fuel based on waste is associated with its calorific value and chemical composition. The energy properties of PBM fuel are summarized in table 3.

Table 3: Energy properties of PBM fuel in comparison to properties of energy industry.

\begin{tabular}{|c|c|c|c|}
\hline Parameter & Unit & PBM fuel & $\begin{array}{c}\text { Requirements stated for } \\
\text { cement industry }[8,9]\end{array}$ \\
\hline LHV & $\mathrm{MJ} / \mathrm{kg}$ & 13.55 & $>13 \mathrm{MJ} / \mathrm{kg}$ \\
\hline HHV & $\mathrm{MJ} / \mathrm{kg}$ & 15.53 & - \\
\hline Moisture & $\%$ & 8.67 & $<30 \%$ \\
\hline Volatile matter & $\%$ & 51.92 & - \\
\hline Ash & $\%$ d.m. & 30.80 & $<40 \%$ \\
\hline \multicolumn{4}{|c|}{ Elementary composition } \\
\hline $\begin{array}{l}\text { Carbon } \mathrm{C} \\
\text { Hydrogen } \mathrm{H} \\
\text { Oxygen } \mathrm{O} \text { and } \\
\text { Nitrogen N } \\
\text { Sulphur S } \\
\text { Chlorine } \mathrm{Cl}\end{array}$ & $\begin{array}{l}\% \\
\text { d.m. }\end{array}$ & $\begin{array}{c}33.47 \\
3.77 \\
\\
22.67 \\
0.62 \\
0.040\end{array}$ & $\begin{array}{l}<2.5 \\
<0.3\end{array}$ \\
\hline
\end{tabular}

d.m. - in dry mass 
The analysis of the energy parameters of PBM fuel leads to the conclusion that the properties of the fuel fulfill the minimum requirements of the cement industry. Hence, it is possible to use, as an alternative substitute, PBM fuel at 10 percent of the total volume of fuel use. A greater content of the new fuel may result in a decrease in the kiln effectiveness and increase of the heat used in the process.

PBM fuel contains a considerable amount of ash. However, one has to bear in mind that the ash resulting from the combustion process is absorbed by the clinker and hence it is necessary to take into consideration its chemical composition while deciding about the input of the raw materials in order not to disturb the relations between the constituents forming the material used for preparation of raw mix.

With regard to emissions, the components which are undesirable include sulfur, chlorine, volatile heavy metals $(\mathrm{Hg}, \mathrm{Cd}$ and $\mathrm{Tl})$ and polychlorinated biphenyls (PCBs), hence, restrictions on their content in alternative fuels have been imposed. The content of the components in the resulting PBM fuel is considerably lower than the admissible levels (tables 3 and 4).

The chlorine content in the meat and bone meal was found equal to around $13 \%$ of the level permitted by the cement industry $(<0.3 \%)$. For example, chlorine content in the PASi fuel (fuel derived from paper, sawdust and liquid waste, i.e. made from solvents, dyes and varnishes) was equal to $0.24 \%$ [9], while in the used car tires (TDF) [10] the content is as much as $0.4 \%$, and in RDF fuel, in the range $0.28 \div 0.7 \%$ [11]. In comparison to hard coal, the fuel from waste has two times smaller concentration of sulfur (with the values in the range $0.5-3.1 \%$ for Polish hard coal, based on the data of ref. [12]).

Table 4: Hazardous material content of in the PBM fuel in comparison to technological restriction imposed on the cement industry.

\begin{tabular}{|c|c|c|c|}
\hline Parameter & Unit & PBM fuel & $\begin{array}{c}\text { Cement industry } \\
\text { requirements }[8,9]\end{array}$ \\
\hline $\begin{array}{l}\text { Heavy metals } \\
\begin{array}{l}\mathrm{Pb} \\
\mathrm{Zn} \\
\mathrm{Sn} \\
\mathrm{Cr} \\
\mathrm{Fe} \\
\mathrm{Cu} \\
\mathrm{Ni} \\
\mathrm{Cd} \\
\mathrm{Tl} \\
\mathrm{Hg}\end{array}\end{array}$ & ppm & $\begin{array}{c}19.43 \\
446.1 \\
0.0304 \\
22.08 \\
2030 \\
43.84 \\
4.92 \\
0.434 \\
0.051 \\
0.421\end{array}$ & $\begin{array}{c}\mathrm{Cd}+\mathrm{Tl}+\mathrm{Hg}<100 \\
<10\end{array}$ \\
\hline PCB* & ppm & $<0.05$ & $<50$ \\
\hline
\end{tabular}

The content of volatile metals $(\mathrm{Hg}, \mathrm{Cd}$ and $\mathrm{Tl})$ is equal to $0.9 \%$ in the $\mathrm{PBM}$ fuel while the admissible level is $100 \mathrm{ppm}$. With regard to $\mathrm{PCB}$, the cement industry set the boundary at $50 \mathrm{ppm}$. Hence, the values of such compounds in PBM fuel are very low (table 4$)$. 
At the same time, the detrimental effect on clinker quality may be associated with heavy metals content in ash in the structure of the resulting cement. They are combined into the structure of cement as a result of very durable chemical processes, which may affect clinker structure and hence lead to the deterioration of cement quality.

A number of references used here list information concerning the negative impact of the elementary composition (including $\mathrm{Pb}, \mathrm{Cb}, \mathrm{Zn}, \mathrm{Cr}, \mathrm{Ni}, \mathrm{As}, \mathrm{Ag}$ and $\mathrm{Ba}$ ) on the quality of Portland cement [13-17]. The content of heavy metals in the gained PBM fuel is summarized in table 4.

The highest concentrations of trace metals in the examined fuel was registered with regard to iron, zinc and chromium, which is connected with the high concentrations of these elements in sewage sludge used for the production of the fuel.

Table 5 illustrates the chemical composition of PBM fuel ash in comparison to the composition of clinker and hard coal ash.

Table 5: Chemical composition of PBM fuel in comparison to the components of clinker and hard coal ash.

\begin{tabular}{|c|c|c|c|c|c|}
\hline $\begin{array}{c}\text { Compound } \\
\text { \% of mass }\end{array}$ & PBM ash & $\begin{array}{c}\text { Hard coal } \\
\text { ash [18] }\end{array}$ & $\begin{array}{c}\text { Blast } \\
\text { furnace slag }\end{array}$ & $\begin{array}{c}\text { Lime } \\
\text { stone }\end{array}$ & Siderite \\
\hline $\mathrm{SiO}_{2}$ & 17.88 & 42.00 & 0.70 & 7.20 & 32.20 \\
\hline $\mathrm{Al}_{2} \mathrm{O}_{3}$ & 4.04 & 20.00 & 38.10 & 2.40 & 12.20 \\
\hline $\mathrm{Fe}_{2} \mathrm{O}_{3}$ & 7.08 & 17.00 & 6.90 & 1.10 & 27.60 \\
\hline $\mathrm{CaO}$ & 42.35 & 5.5 & 42.50 & 48.60 & 2.60 \\
\hline $\mathrm{MgO}$ & 0.95 & 2.1 & 7.10 & 0.40 & 2.40 \\
\hline $\mathrm{P}_{2} \mathrm{O}_{5}$ & 21.06 & - & - & 1.5 & - \\
\hline $\mathrm{TiO}_{2}$ & 0.36 & 1.2 & - & - & - \\
\hline $\mathrm{SO}_{3}$ & 0.50 & 5.0 & - & 0.60 & 3.20 \\
\hline $\begin{array}{c}\text { Compounds } \\
\text { not marked }\end{array}$ & & & & & \\
\hline
\end{tabular}

The main oxides included in PBM fuel ash include: $\mathrm{CaO}, \mathrm{SiO}_{2}, \mathrm{Fe}_{2} \mathrm{O}$ and $\mathrm{Al}_{2} \mathrm{O}_{3}$, the list of which is the same as in the raw materials used for clinker production. However, the high content of $\mathrm{P}_{2} \mathrm{O}_{5}$ is not beneficial since it affects the hydraulic activity of cement. The content of $\mathrm{P}_{2} \mathrm{O}_{5}$ in clinker must not exceed $0.2-0.3 \%$, hence in the application in PBM fuel it is necessary to pay attention to volume of batched fuel which, besides, must conform to the requirements concerning calorific value and must not display undesired properties.

The experience gained in the cement industry leads to the conclusion that the 20 percent $\mathrm{P}_{2} \mathrm{O}_{5}$ content in the meal will render it possible to use it for kiln entry in the volume, which corresponds to 5 percent of heat demand. 
In order to observe the changes occurring in the fuel under the influence of high temperature, differential thermal analysis (DTA) and thermogravimetric analysis (TG) were undertaken within the range of temperatures from 0 to $1200^{\circ} \mathrm{C}$ in air atmosphere. The course of TG and DTA analysis is illustrated in fig. 2.

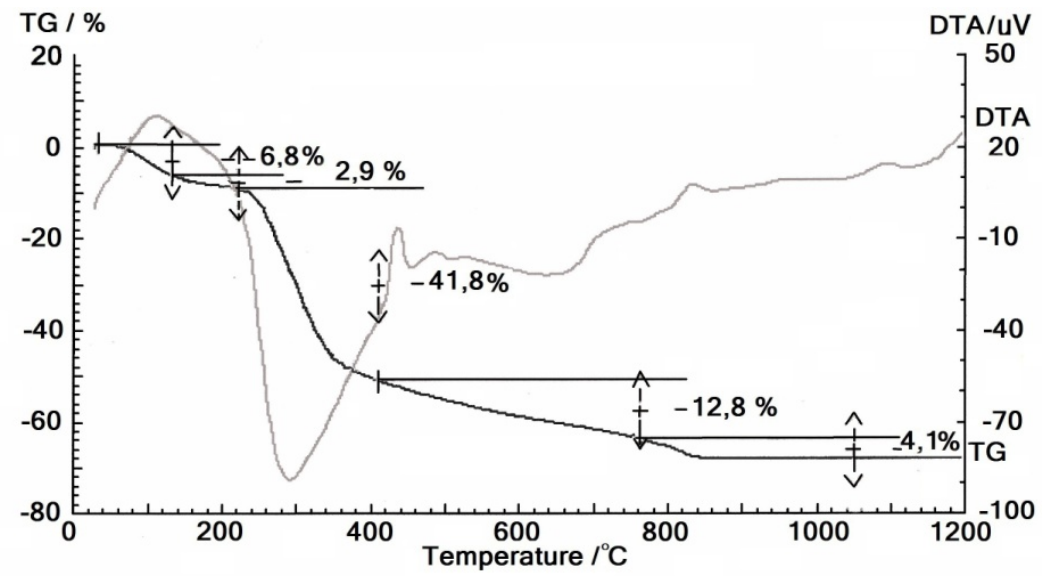

Figure 2: TG and DTA analysis of PBM fuel.

On the basis of analysis of the thermogram, it is possible to conclude that up to a temperature of $150^{\circ} \mathrm{C}$, a slight loss of mass follows corresponding to evaporation of the internal moisture. The biggest exothermic peak is noted for a temperature of around $240^{\circ} \mathrm{C}$, which is associated with the fuel ignition. The process of combustion occurs up to a temperature of $820^{\circ} \mathrm{C}$. The mass loss associated with the burnout of the organic substance is equal to $90 \%$. For a temperature of around $830^{\circ} \mathrm{C}$, it is possible to note a slight endothermic effect resulting from the decomposition of calcium carbonate present in the ash.

Apart from the chemical properties of the fuel, it must also fulfill the requirement of ensuring stability, homogeneity of the composition and physical properties.

Some of the other properties, which are particularly relevant to the cement industry, include those which promote its transport, storage and batching. The examinations conducted on the PBM fuel confirm the applicability of the granulated form for application in the kiln. The PBM fuel with $35 \mathrm{~mm}$ granulation is shown in fig. 3 and the bulk density is given in table 6 .

Stability of the fuel form is extremely important during its transport and storage. This parameter can be assessed by marking its drop strength. This test determines the changes in the structure of fuel when it is dropped from a height of $1.5 \mathrm{~m}$ on a concrete foundation under standardized conditions. 


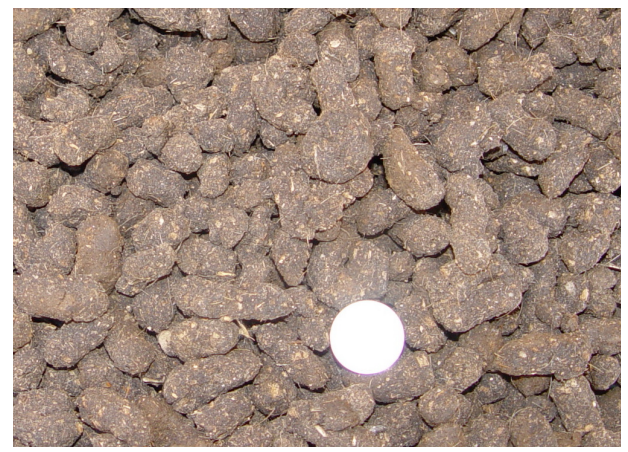

Figure 3: PBM fuel.

When fuel is stored, it is often influenced by unfavourable atmospheric conditions, which may negatively affect fuel-hardness. This may be mostly influenced by the change in fuel-moisture as a result of its moisture absorption from the surroundings and precipitation. Therefore, its water resistance is still another specified parameter, which is defined as the degree of change in the drop strength of fuel formed as a result of water absorption.

Table 6: Bulk density of PBM fuel.

\begin{tabular}{|c|c|c|c|}
\hline Parameter & \multirow{2}{*}{ Unit } & $\begin{array}{c}\text { Granulation } \\
25 \mathrm{~mm}\end{array}$ & $\begin{array}{c}\text { Granulation } \\
35 \mathrm{~mm}\end{array}$ \\
\hline PBM fuel & & 480 & 325 \\
\cline { 1 - 1 } $\begin{array}{c}\text { Biomass } \\
\text { pellets [8] }\end{array}$ & \multirow{2}{*}{$\mathrm{kg} / \mathrm{m}^{3}$} & \multicolumn{2}{|c|}{$500-780$} \\
\cline { 3 - 4 } $\begin{array}{c}\text { Brawn coal } \\
\text { briquettes [12] }\end{array}$ & & \multicolumn{2}{|c|}{$700-725$} \\
\cline { 3 - 4 } & & \multicolumn{2}{|c|}{} \\
\cline { 3 - 4 }
\end{tabular}

PBM fuel was subsequently subjected to the testing of its resistance to frost. The fuel was subjected to 50 cycles of frosting and defrosting. Each cycle involved freezing the fuel to $-18^{\circ} \mathrm{C}$, and subsequent defrosting to $18^{\circ} \mathrm{C}$. Following that, the resistance of the fuel to drop was tested. The results of this research are presented in fig. 4. The analysis of the results of fuel drop strength confirms that it fully fulfills the necessary strength properties.

On the basis of the conducted research, an observation was made that water has a detrimental effect on the strength of the fuel. It was found that after the fuel absorbs water, its strength tends to drop dramatically. At the same time, the examination of fuel resistance to frost leads to the conclusion that the strength of the fuel after the test fell only by $8 \%$.

The conclusion from the above is that the fuel should be stored in the area protected from rainfall. 


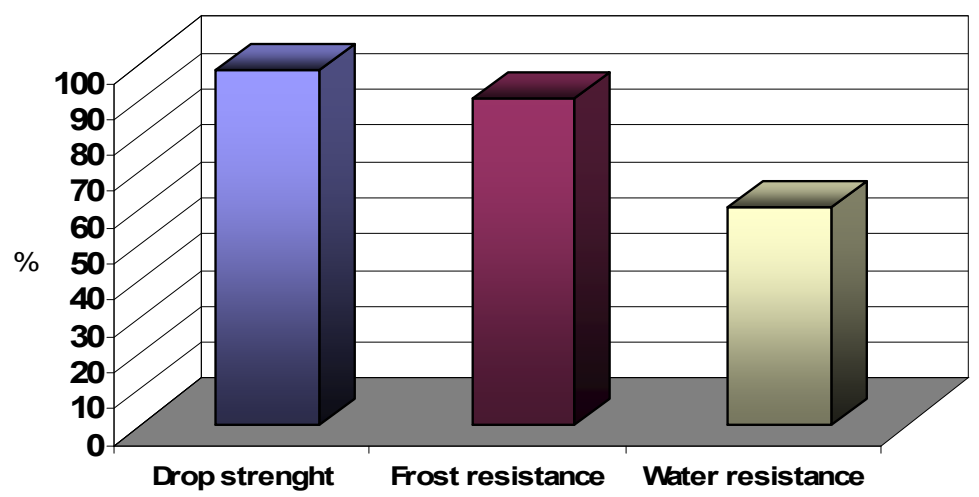

Figure 4: Physical properties of PBM fuel.

The physical properties of briquettes and pellets are to a large degree related to their internal structure. The orientation of grains in the components and binding agent, the occurrence of hollow spaces and cracks and structural faults affect the strength properties of the fuel forming in the process. The assessment of the internal structure of fuels involved the application of computer analysis of the image resulting from the observation of fuel under a microscope (Studar company) and a dedicated software. A sample image with waste and meat and bone meal fuel is presented in fig. 5 .

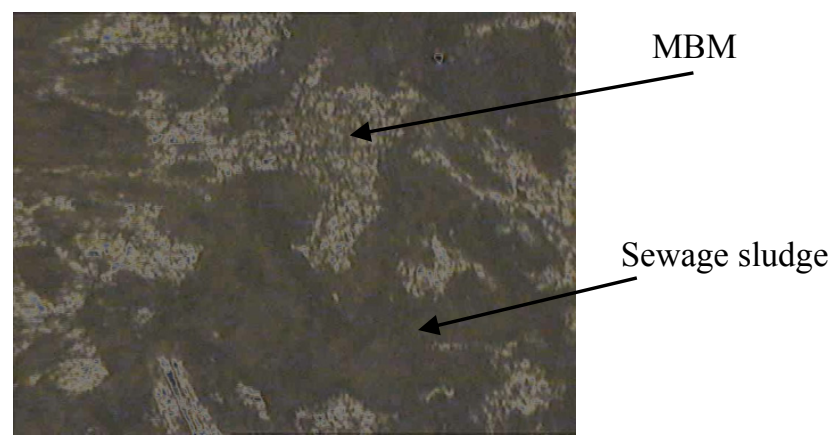

Figure 5: Structure of PBM fuel in 5 times magnification.

By observing the structure of PBM fuel, one can note that the grains in the components the fuel tend to accumulate forming bigger agglomerations.

An important consideration during the production of PBM fuel is associated with good mixing of the components of the fuel since it has an influence on its strength properties (lower drop resistance or too high fuel fragility).

Fuel based on sewage sludge and meat and bone meal has to be manufactured in a plant which is capable to process waste to produce fuel or on a site of a wastewater treatment plant as a final stage of processing sewage sludge to prepare it for energy use. 


\section{Conclusions}

The conducted examinations and analysis leads to the following practical conclusions:

- The application of meat and bone meal as component of granulated fuel may be an alternative for an installation to which the input of animal meal may be undesirable.

- The combined use of meat and bone meal and sewage sludge enables the full application of its energy potential.

- $\quad$ PBM fuel displays properties which fulfill the requirements usually adopted by the cement industry and may be applied as a substitute of coal in the process of clinker cement burning.

- The only problem may be associated with the high content of $\mathrm{P}_{2} \mathrm{O}_{5}$ in fuel ash, which must be taken into consideration in the determination of maximum $\mathrm{P}_{2} \mathrm{O}_{5}$ content in the resulting clinker not exceeding the admissible level.

- The properties associated with high water absorption result in the deterioration of the mechanical properties of the fuel. For that reason the fuel should be ensured dry storage facilities.

- The produced fuel can be introduced into the chamber located between the cyclone preheater and the rotary kiln or into the precalciner burner installed in the state-of-the art in modern kiln installations. Those are the places where the kiln can be charged with low-energy fuels showing a high moisture content and likely to contain a larger amount of mineral matter.

- $\quad$ The physical composition and form of the produced PBM fuel makes it applicable for other processes of industrial fuel combustion, e.g., in the process of co-combustion with coal in the existing power plants and heat generating plants.

\section{Acknowledgement}

The research was carried out within the project No. 0464/R/2/T02/06/01 funded by the Minister of Science and Higher Education.

\section{References}

[1] Schedule of restructuring and modernization of utility industry in Poland Warsaw, 2002 /in Polish/.

[2] Regulation (EC) No 1774/2002 of the European Parliament and of the Council of 3 October 2002 laying down health rules concerning animal byproducts not intended for human consumption.

[3] Gulyurtlu, I. \& Boavida, D., Abelha, P., Lopes, M.H. \& Cabrita, I., Co-combustion of coal and meat and bone meal. Fuel, 8(4), pp. 2137-2148, 2005. 
[4] Skodras, G., Grammelis, P. \& Basinas, P., Pyrolysis and combustion behaviour of coal-MBM blends. Bioresource Technology, 98, pp. 1-8, 2007.

[5] McDonnell, K., Desmond, J., Leahy, J.J., Howard-Hildige, R. \& Ward, S., Behaviour of meat and bone meal/peat pellets in a bench scale fluidized bed combustor. Energy, 26(1), pp. 81-90, 2001.

[6] Van Loo, W., Alternative Fuels: The Valorisation of Waste in the Cement Industry, CEMBUREAU, Warsaw, 2005.

[7] Wzorek, M., Experimental Verification of a Model of forming Fuels from Waste based on Example of Municipal Sewage Sludge, Studies and Monographs, No. 346, Publishing House of Technical University of Opole, Opole, 2013 /in Polish/.

[8] Wzorek, M., Characterization of the properties of alternative fuels containing sewage sludge. Fuel Processing Technology, 104, pp. 80-89, 2012.

[9] Mokrzycki, E. \& Uliasz-Bocheńczyk, A., Use of alternative fuels for the cement industry. Applied Energy, 74, pp. 95-100, 2003.

[10] Pipilikaki, P., Katsioti, M., Papageorgiou, D., Fragoulis, D. \& Chaniotakis, E., Use of tire derived fuel in clinker burning. Cement and Concrete Composites, 27(7-8), pp. 843-847, 2005.

[11] Genon, G. \& Brizo, E., Perspective and limits for cement kilns as a destination for RDF. Waste Management, 28, pp. 2375-2385, 2008.

[12] Wandrasz, W. \& Wandrasz, A.J., Formed fuels, Seidel-Przywiecki Publishing House, Warsaw, 2006 /in Polish/.

[13] Murat, M. \& Sorrentino, F., Effect of large additions of Cd, Pb, Cr, Zn, to cement raw meal on the composition and the properties of the clinker and the cement. Cement and Concrete Research, 28, pp. 329-333, 1998.

[14] Stephan, D., Mallmann, R., Knöfel, D. \& Härdtl, R., High intakes of Cr, Ni, and $\mathrm{Zn}$ in clinker Part I. Influence on burning process and formation of phases. Cement and Concrete Research, 29, pp. 1949-1958, 1999.

[15] Trezza, M.A. \& Scian, A.N., Waste fuels: their effect on Portland cement clinker. Cement and Concrete Research, 35, pp. 438-444, 2005.

[16] Karagiannis, J., Fitkos, F.J. \& Nikolopoulus, P., The use of wastes as alternative fuels in cement production, Waste Management and the Environment $I V$, eds. M. Zamorano, V. Popov, A. Kungolos, C.A. Brebbia, \& H. Itoh, WIT Press, Southampton, pp. 105-114, 2008.

[17] Wzorek, M., Baran, T. \& Ostrowski, M., The influence of ash absorption from secondary fuels combustion on clinkering process and hydraulic activity of Portland cement clinker. Cement-Wapno-Beton [Cement-LimeConcrete], 4, pp. 207-215, 2013.

[18] Kikuchi, R., Recycling of municipal solid waste for cement production: pilot-scale test for transforming incineration ash of solid waste into cement clinker. Resources, conservation and Recycling, 32, pp. 137-147, 2001. 